\title{
Familial Hypercholesterolemia with Tendinous Xanthomas and Achilles Tendinitis - A Forgotten Dermato-Rheumatologic Association
}

\author{
Puspanjuli SAHU', Saritha MOHANAN², Carounanidy UDAYSHANKAR², Sankappa P. SIN- \\ HASAN $^{2}$, Ramachandra V. BHAT \\ ${ }^{1} \mathrm{Hi}$-Tech Medical College \& Hospital, Rourkela \\ 2Department of Dermatology, IGMC\&RI, Puducherry \\ *Correspondence: Saritha Mohanan, E-mail: saritha_mohanan@yahoo.co.in
}

UDC 616.153.7-056.7-06:616.52 and 616.153.7-056.7-06:616-002.77

\begin{abstract}
Familial hypercholesterolemia $(\mathrm{FH})$ is a disorder of lipoprotein metabolism with dermatological and rhematological manifestations. Tendinous xanthomata (TX) are a hallmark of this disease. They are associated with recurrent tendinitis and tendon damage, an aspect of the clinical presentation, which is not well-known among dermatologists. We report two cases of heterozygous familial hypercholesterolemia, where the patients started developing tendinous xanthomata early in their life, with progressive increase in the number and size of lesions. However, they presented late, only when the recurrent attacks of tendinitis became severe .We present these cases to highlight the rheumatologic features, which may be the first symptom of heterozygous familial hypercholesterolemia.
\end{abstract}

Key words: Hyperlipoproteinemia Type II; Xanthomatosis; Achilles Tendon; Heterozygote; Genetic Predisposition to Disease; Rheumatic Diseases

\section{Introduction}

Familial hypercholesterolemia $(\mathrm{FH})$ is a familial metabolic disorder characterised by high serum concentration of low-density lipoprotein (LDL) cholesterol, corneal arcus, tendinous xanthomata (TX) and premature atherosclerosis (1). Rhematological manifestations, though not uncommon, are not usually highlighted in dermatology literature. Tendinitis, tenosynovitis, arthralgia, and migratory polyarthritis have been described in these patients (2). We report two cases with dermatological and rheumatic manifestations in order to stress the importance of awareness of the rheumatologic manifestations.

\section{Case 1}

A 41-year-old woman, born of third degree consanguineous marriage, was referred to Dermatology OPD with multiple painful skin-coloured nodules over the joints of the hands, elbows, knees and the ankle along with fever. The nodular lesions started devel- oping in the second decade of her life, with progressive increase in the number and size of lesions. There was history of recurrent attacks (2-3 episodes/year) of inflammation of the nodules and nearby joints, associated with fever, from the third decade of her life. The attacks were mild and subsided with a short course of non-steroidal anti-inflammatory drugs.

Physical examination revealed multiple, skin coloured, firm to hard, subcutaneous nodules over the extensor aspect of the small joints of the hands and elbows (Figure 1), with larger lesions over the knee and pedunculated lesions over the hip joints. She also had xanthelasma palpebrarum and diffuse thickening of the bilateral Achilles tendons (Figure 2). There was warmth, swelling and focal tenderness over the nodules of hand and the Achilles tendon. The joints were normal. Systemic and ophthalmologic examinations were normal.

Her blood counts were normal. Erythrocyte sedimentation rate was elevated $\left(110 \mathrm{~mm} / 1^{\text {st }} \mathrm{hr}\right)$ 


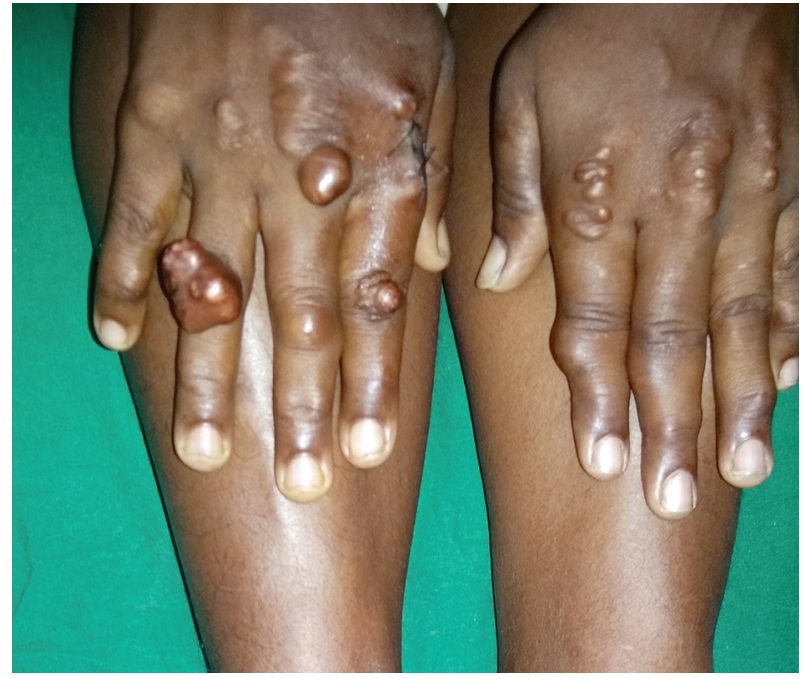

Figure 1: Multiple tendinous xanthomata on bilateral hands, elbows and feet of patient 1.

and C-reactive protein was positive. Antistreptolysin $\mathrm{O}$ titre, rheumatoid factor, antinucelar antibodies, and serum uric acid were within normal range. Fasting lipid profile was abnormal (Table 1). Radiography of the bilateral hands did not show any bone abnormality. Fine needle aspiration cytology (FNAC) revealed foam cells, touton and foreign body giant cells and mixed chronic inflammatory cells. Transthoracic echocardiography was normal. DNA testing was not done due to financial constraints. Histopathological examination of the subcutaneous nodule showed the thinned out epidermis with well circumscribed collection of xanthomatous cells (foamy cells), few cholesterol clefts, touton cells and foreign body giant cells in the superficial dermis extending deep into dermis (Figures 3,4). Based on clinical examination and investigations, a diagnosis of $\mathrm{FH}$ with tendinous and tuberous xanthomata with acute tendinitis was made.
The patient was started on Atorvastatin $40 \mathrm{mg}$ and analgesics. Fever, pain and swelling of nodules improved within three days of treatment. The patient was examined in our OPD after 3 months. Xanthomas decreased in size and became soft, without episodes of tendinitis in the meantime.

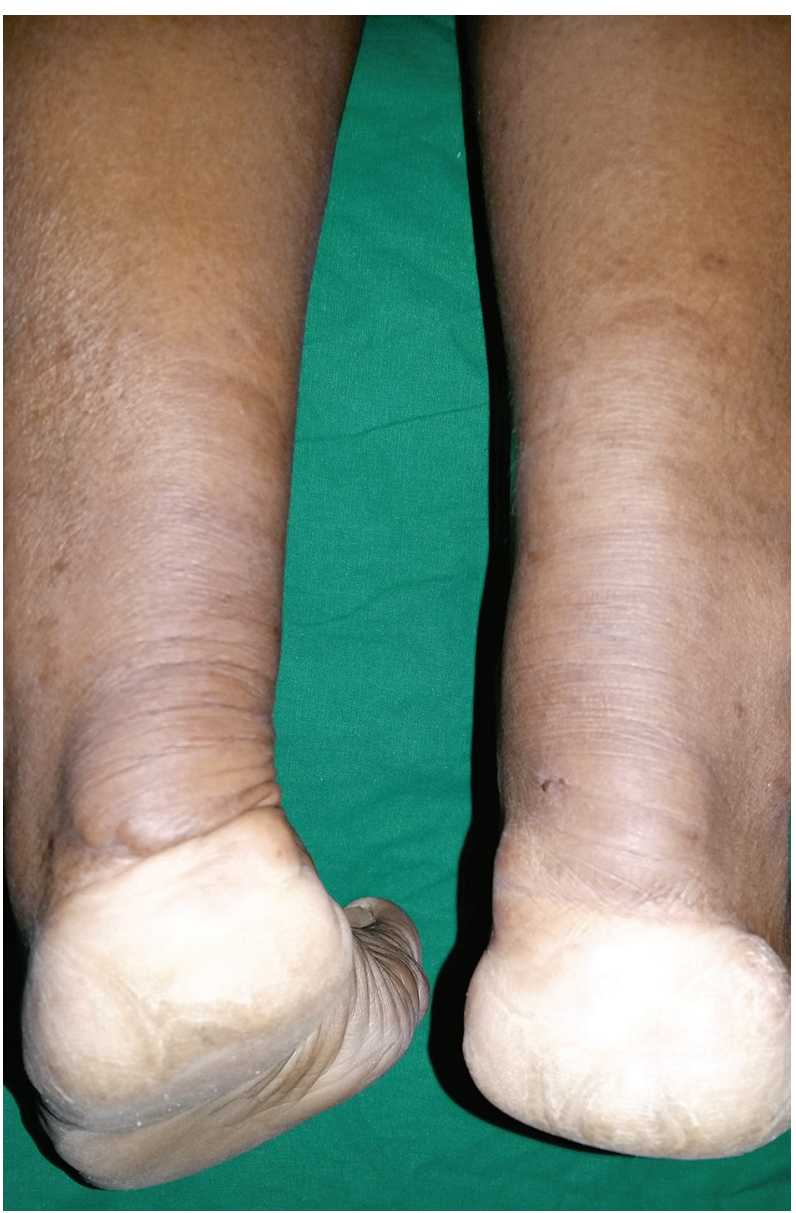

Figure 2. Diffuse thickening of Achilles tendons of patient 1

Table 1: Lipid profile of Patient 1 and Patient 2

\begin{tabular}{lccc} 
Fasting lipid profile & Patient 1 & Patient 2 & Reference range \\
Cholesterol & 524 & 562 & $130-240 \mathrm{mg} / \mathrm{dl}$ \\
Triglycerides & 168 & 228 & $65-165 \mathrm{mg} / \mathrm{dl}$ \\
HDL Cholesterol & 29 & 31 & $>35 \mathrm{mg} / \mathrm{dl}$ \\
LDL Cholesterol & 351 & 531 & $130-159 \mathrm{mg} / \mathrm{dl}$ \\
Cholesterol/HDL ratio & 18.07 & 18.13 & $0.0-0.0$ \\
\hline
\end{tabular}

HDL-High Density lipoprotein; LDL-low density lipoprotein 


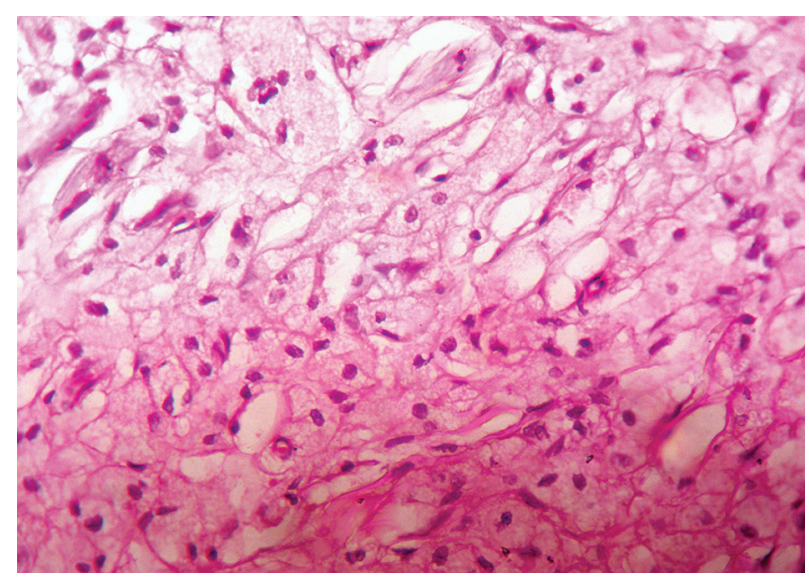

Figure 3. Xanthoma cells displaying foamy cytoplasm admixed with few cholesterol clefts $(\mathrm{H}$ and E stain, $40 \mathrm{X}$ magnification)

\section{Case 2}

A 48-year-old female patient came to Dermatology OPD with similar complaints, along with ulceration of a larger pedunculated lesion over the left gluteal region. The nodules started appearing in the third decade of her life and during the last 5 years, she suffered from four to five episodes of swelling and pain over the lesions along with fever every year. There was a partial restriction of joint mobility during these episodes, which subsided within four to five days, without any residual joint problem. There was no similar history in other family members.

Physical examination showed similar features with ulcer of size $3 \times 3 \mathrm{~cm}$ over the pe-

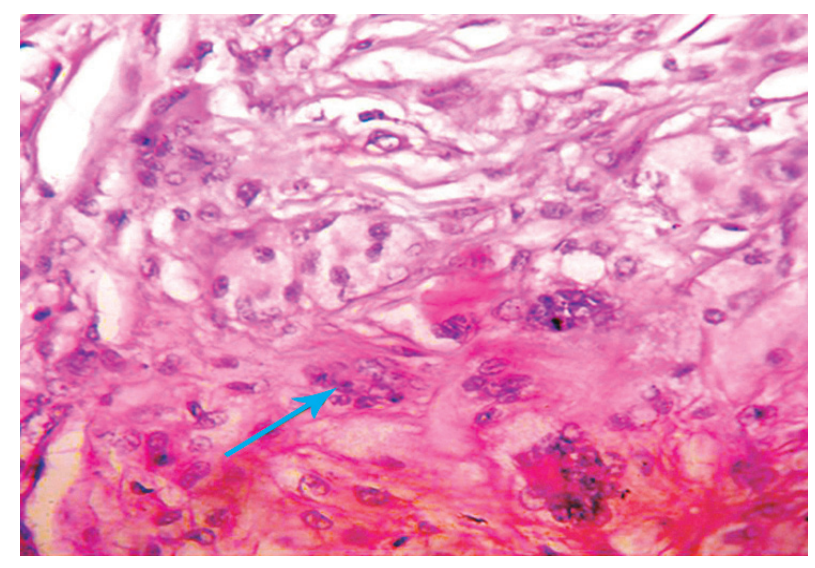

Figure 4. Presence of numerous multinucleated giant cells (arrow) admixed with xanthoma cells and cholesterol clefts ( $\mathrm{H}$ and $\mathrm{E}$ stain, $40 \mathrm{X}$ magnification) dunculated lesion on the left gluteal region (Figure 5). FNAC revealed lipid laden foaming macrophages along with touton gaint cells, lymphocytes, plasma cells with fibrocollagenous stromal fragments. Fasting lipid profile was deranged (Table 1). Skin biopsy was not done as the patient did not give consent. She was prescribed atorvastatin $40 \mathrm{mg}$. She was lost to follow up after that.

\section{Discussion}

Familial hypercholesterolemia is a common autosomal codominant disease caused by defects in the LDL receptor gene (3). In the homozygous form of the disorder, LDL cholesterol levels are above $500 \mathrm{mg} / \mathrm{dl}$ and xanthomata appear during infancy and childhood. In the heterozygous form, LDL cholesterol levels are around $300 \mathrm{mg} / \mathrm{dl}$, tendinous xanthomata (TX) appear in the second and third decades of life (2). In our patients, the lipid profile was suggestive of heterozygous type Ila hyperlipoproteinemia and xanthomata started appearing in the second and third decade of life respectively.

The dermatological manifestations occur in form of multiple types of xanthomas such as tendinous, tuberous, subperiosteal xanthomas, and xanthelasma. Intertriginous xanthomas are rare, but if present, they are pathognomonic of this disorder (4). In both of our patients, tendinous, tuberous xanthomas and xanthelasma palpebrarum were the typical manifestations. TX deposits are highly specific of $\mathrm{FH}$, and current recommendations include them as an important clinical diagnostic criterion (5). In these subjects, LDL receptor defect results in the formation of oxidized LDL

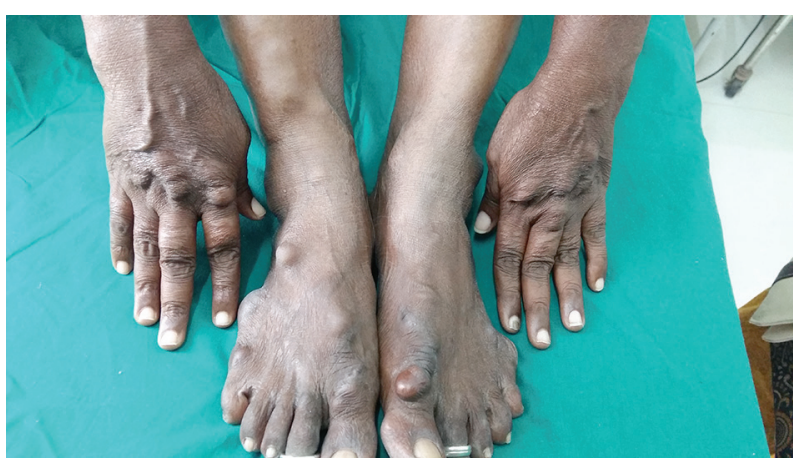

Figure 5. Multiple tendinous xanthomata on bilateral hands, elbows and feet of patient 1 
(oxLDL), and uptake by the macrophage receptors, leading to massive lipid accumulation and foam cell formation (6).These foam cells, extracellular unesterified and esterified cholesterol and connective tissue are the main components of tendon xanthomas $(7,8)$.

The clinical expression of heterozygous $\mathrm{FH}$ is highly variable in terms of the severity of hypercholesterolemia, the presence of TX, and the age of onset and severity of CAD, even in subjects sharing the same LDL receptor gene defect (9). The macrophages from $\mathrm{FH}$ patients TX + have higher inflammatory response to oxLDL than those from FH subjects TX- and a resultant higher predisposition to form foam cells, due to differential expression of HLA-II and FccRllb. In these cases, a strong upregulation of tryptase and a specific tryptase expression have been observed. They reduce the efflux of cholesterol from macrophages and activate peripheral mononuclear cells for the release of TNF-a, IL-6 and $\mathrm{IL}-1 \mathrm{~b}$, thereby mediating inflammation (10).

Among the different types of xanthomata, TX cause significant rheumatological manifestations. They are usually skin colored and hard due to fibrosis (4). Predilection sites of TX are Achilles tendons, tendons on the backs of the hands and fingers, as well as elbows, knees and heels (11). The rheumatologic manifestations include recurrent Achilles tendon's pain, acute mono-oligoarthritis and migratory polyarthritis (rheumatic fever type) (12). A typical attack of polyarthritis coincides with a slight but definite rise in the plasma cholesterol concentration (1). The articular manifestations in heterozygous $\mathrm{FH}$ are frequent, diverse, recurrent, incapacitating and short. The joints remains symptom free between attacks, and they never progress to articular damage or deformity as observed in the homozygous $\mathrm{FH}(2)$.

In our patients, rheumatologic manifestations were in form of acute tendinitis, not only of Achilles tendon, but almost all the tendons that were infiltrated with xanthomata. Repeated inflammation in the xanthomas caused fibrosis, leading to hard consistency mimicking calcinosis cutis. These cases can be mistaken for rheumatoid arthritis, tophaceous gout, psuedogout because the presentation is quite similar.
Systemic inflammation can cause lipid profile changes (13). Conversely, lipids can have a direct modulating effect on inflammation by increasing the circulatory inflammatory cells and proinflammatory cytokines TNF-a and IL-6 $(10,14)$. In our patients, a transient rise in plasma cholesterol concentration might have stimulated the genetically modified macrophages in TX and in peripheral blood; thereby producing a higher inflammatory response resulting in acute tendinitis and fever.

We report these cases of heterozygous $\mathrm{FH}$ because of its typical manifestation of various types of xanthomas and highlight the presentation of recurrent acute tendinitis along with fever as part of $\mathrm{FH}$, which has not been discussed in literature on dermatology so far to the best of our knowledge.

\section{References}

1. Carroll GJ, Bayliss CE. Treatment of arthropathy of familial hypercholesterolaemia. Ann Rheum Dis. 1983;42(2):206-9.

2. Mathon G, Gagne C, Brun D, Lupien PJ, Moorjani S. Articular manifestations of familial hypercholesterolaemia. Ann Rheum Dis. 1985;44(9):599-602.

3. Brown MS, Goldstein JL. A receptor-mediated pathway for cholesterol homeostasis. Science. 1986;232 (4746):34-47.

4. Braun-Falco O, Plewig G, Wolff HH, Winkelmann RK. Skin disorders caused by disturbances of lipid metabolism. In: Braun-Falco O, Plewig G, Wolff HH, Winkelmann RK. Dermatology. Berlin: Springer; 1991. p. 849-60.

5. Civeira F; International Panel on Management of Familial Hypercholesterolemia. Guidelines for the diagnosis and management of heterozygous familial hypercholesterolemia. Atherosclerosis. 2004;173(1):55-68.

6. Linton MF, Fazio S. Class A scavenger receptors, macrophages and atherosclerosis. Curr Opin Lipidol. 2001;12(5):489-95.

7. Kruth HS. Lipid deposition in human tendon xanthoma.Am J Pathol. 1985;121(2):311-5.

8. Tall AR, Small DM, Lees RS. Interaction of collagen with the lipids of tendon xanthomata. J Clin Invest. 1978;62(4):836-46.

9. Ferrieres J, Lambert J, Lussier-Cacan S, Davignon J. Coronary artery disease in heterozygous familial hypercholesterolemia patients with the same LDL receptor gene mutation. Circulation. 1995;92(3):290-5.

10. Artieda M, Cenarro A, Junquera C, Lasierra P, Martínez-Lorenzo MJ, Pocoví M, et al. Tendon xanthomas in familial hypercholesterolemia are associated with a differential inflammatory response of macrophages to oxidized LDL. FEBS Lett. 2005;579(20):4503-12. 
11. Zak A, Zeman M, Slaby A, Vecka M. Xanthomas: clinical and pathophysiological relations. Biomed Pap Med Fac Univ Palacky Olomouc Czech Repub. 2014;158(2):181-8.

12. Chakraborty PP, Mukhopadhyay S, Achar A, Pal M, Mondal PC. Migratory polyarthritis in familial hypercholesterolemia (type Ila hyperlipoproteinemia). Indian J Pediatr. 2010;77(3):329-31.
13. Myasoedova E, Crowson CS, Kremers HM, Roger VL, Fitz-Gibbon PD, Therneau TM, et al. Lipid paradox in rheumatoid arthritis: the impact of serum lipid measures and systemic inflammation on the risk of cardiovascular disease. Ann Rheum Dis. 2011;70(3):482-7.

14. Drechsler M, Megens RT, van Zandvoort M, Weber C, Soehnlein O. Hyperlipidemia triggered neutrophilia promotes early atherosclerosis. Circulation. 2010;122 (18):1837-45.

\section{Porodična hiperholesterolemija sa tendinoznim ksantomima i Ahilovom petom - zaboravljena dermatovenerološka veza}

\section{Sažetak}

Porodična hiperholesterolemija $(\mathrm{PH})$ je poremećaj metabolizma lipoproteina sa dermatološkim i reumatološkim manifestacijama. Tendinozni ksantomi (TK) su obeležje ovog oboljenja. One su združene sa recidivnim tendinitisom i oštećenjem tetive, a to je aspekt kliničke prezentacije koji nije dobro poznat među dermatolozima. Prikazana su dva slučaja heterozigotne porodične hiper- holesterolemije, u kojima su pacijenti počeli da dobijaju tendinozne ksantome rano u životu, a broj i veličina povreda su progresivno rasli. Međutim, oni su se javili kasno, tek kada su recidivni napadi tendinitisa postali teški. Prikazujemo te slučajeve da bismo objasnili reumatološke osobine, koje mogu biti prvi simptom heterozigotne porodične hiperholesterolemije.

Ključne reči: Hiperlipoproteinemija tipa 2; Ksantomatoza; Ahilova tetiva; Heterozigot; Genetska predispozicija prema bolesti; Reumatske bolesti

Received 24.03.2019.

Accepted 29.04.2019. 